\title{
Supporting Accused Persons with Cognitive Disabilities to Participate in Criminal Proceedings in Australia: Avoiding the Pitfalls of Unfitness to Stand Trial Laws
}

\author{
Piers Gooding, Anna Arstein-Kerslake, \\ Sarah Mercer and Bernadette McSherry
}

\begin{abstract}
In the 10 years since Australia has ratified the United Nations Convention on the Rights of Persons with Disabilities (CRPD), the issue of the indefinite detention of persons with cognitive disabilities found unfit to stand trial has received considerable attention. Concerns have been raised by national media, law reform bodies and United Nations human rights agencies. Yet there remain few examples of formal change to unfitness to stand trial laws in Australia. This article focuses on the role of procedural accommodations in meeting CRPD requirements, and other accessibility measures to ensure accused persons with cognitive disabilities are able to take part in criminal proceedings on an equal basis with others. It examines support measures that appear in existing statute and case law within Australia and considers the need to develop new forms of support.
\end{abstract}

\section{INTRODUCTION}

The equality demands of the United Nations Convention on the Rights of Persons with Disabilities (CRPD) ${ }^{1}$ raise difficult questions about unfitness to stand trial laws. In Australia, as in most common law countries, unfitness to stand trial laws create separate legal processes for accused persons deemed unable to understand or participate in criminal proceedings. ${ }^{2}$ This differential treatment is typically justified on the grounds of protection (for example, to prevent unfair trials where a person cannot understand proceedings and cannot challenge claims made against him or her) ${ }^{3}$ and/or efficiency (where accused persons with disabilities are diverted away from the criminal justice system and into services

1 Convention on the Rights of Persons with Disabilities, opened for signature 30 March 2007, 2515 UNTS 3 (entered into force 3 May 2008) (CRPD).

2 See, for example, Crimes Act 1900 (ACT) s 316(1); Mental Health (Forensic Provisions) Act 1900 (NSW) s 21(1); Criminal Code Act 1983 (NT) s 43W(1); Criminal Justice (Mental Impairment) Act 1999 (Tas) s 16(1); Crimes (Mental Impairment and Unfitness to be Tried) Act 1997 (Vic) s 16(1).

3 Australian Law Reform Commission, Equality, Capacity and Disability in Commonwealth Laws, Report 124 (2014) 73. 
in community or custodial settings) ${ }^{4}$ However, in practice, unfitness to stand trial laws can result in inequitable outcomes, ${ }^{5}$ including indefinite detention of accused persons in prisons and other custodial settings for longer than if they had been convicted and sentenced in a typical trial. ${ }^{6}$ Among other issues, these outcomes may put pressure on the accused to plead guilty in order to avoid the consequences of being found unfit to stand trial. ${ }^{7}$ In addition, the 'special hearings' that typically follow a finding of unfitness fail to secure the due process safeguards of typical trials, such as offering the same evidentiary standards and available defences. $^{8}$

Australia has been criticised at the international level for its unfitness to stand trial laws. Critics include the United Nations Human Rights Council and the Committee on the Rights of Persons with Disabilities (CRPD Committee). ${ }^{9}$ The CRPD Committee, which is the monitoring body for the CRPD,${ }^{10}$ found that the indefinite detention of Australians with 'intellectual or psychosocial disability' under unfitness to stand trial laws violated the CRPD, and called on Australia to 'establish binding guidelines to ensure appropriate support and accommodations for persons with disabilities in the criminal justice system'. ${ }^{11}$ In late 2016, the CRPD Committee heard an individual complaint, made on behalf of Marlon Noble, an Indigenous man from Western Australia, who was incarcerated for close to 10 years after being found unfit to stand trial following an alleged sexual assault. ${ }^{12} \mathrm{Mr}$ Noble remains on an indefinite, non-custodial supervision order at the time of writing, ${ }^{13}$ despite the alleged victims for his original charge having informed prosecutors that he never assaulted

$4 \quad$ See, for example, Thomson Reuters, The Laws of Australia, [9.3.1950], [9.3.2010][9.3.2030]; Russ Scott, 'Court-Ordered Treatment for Offenders with Mental Illness' (2008) 16 Journal of Law and Medicine 405.

5 See Ian Freckelton and Hugh Selby, Expert Evidence: Law, Practice, Procedure and Advocacy (Lawbook Co, 4th ed, 2009) 770.

6 Australian Law Reform Commission, above n 3, 196.

7 Ibid [7.20].

8 Piers Gooding et al, 'Unfitness to Stand Trial and the Indefinite Detention of Persons with Cognitive Disabilities in Australia: Human Rights Challenges and Proposals for Change' 40(3) Melbourne University Law Review 816.

$9 \quad$ Human Rights Council, Report of the Working Group on the Universal Periodic Review of Australia: Views on Conclusions and/or Recommendations, Voluntary Commitments and Replies Presented by the State under Review, 31st sess, UN Doc A/HRC/31/14/Add.1 (29 February 2016); Committee on the Rights of Persons with Disabilities, Concluding Observations on the Initial Report of Australia, 10th sess, UN Doc CRPD/C/AUS/CO/1 (21 October 2013) 4 [31]-[34].

10 CRPD Art 34.

11 Committee on the Rights of Persons with Disabilities, above n 9, [31].

12 Committee on the Rights of Persons with Disabilities, Views: Communication No 7/2012, 16th sess, UN Doc CRPD/C/16/D/7/2012 (2 September 2016) 17 [8.9].

13 Karen Barlow (Australian Broadcasting Commission), 'Sexual Assault Charges against WA Man in Doubt', Lateline (online), 18 April $2011<\mathrm{http}: / /$ www.abc.net. $\mathrm{au} /$ lateline/content/2011/s3195017.htm>. 
them. ${ }^{14}$ The CRPD Committee referred to 'the irreparable psychological effects that indefinite detention may have on the detained person' and determined 'that the indefinite detention [Mr Noble] was subjected to amounted to inhuman and degrading treatment'. ${ }^{15}$

One major question raised by the CRPD is whether unfitness to stand trial laws are inherently disabling because they create a differential form of justice for people with cognitive impairments. ${ }^{16}$ Tina Minkowitz, for example, has argued that criminal procedures need to be universally accessible and that no assessments of competency should be used to activate alternative procedures. ${ }^{17}$ The CRPD Committee seems to endorse this view. ${ }^{18}$ In contrast, the Law Commission of England and Wales has argued that unfitness to plead rules could be construed as an 'accessibility measure' in which modified proceedings help secure substantive equality. ${ }^{19}$ In other words, differential treatment can be justified to avoid unfair outcomes for accused persons with disabilities. We have explored this debate elsewhere, ${ }^{20}$ including with a focus on Australian criminal law, ${ }^{21}$ and have concluded that modified proceedings that only apply to people with cognitive disabilities are most likely not compliant with the CRPD because they often result in longer sentences and other negative differential treatment.

This article focuses on one quite practical step in the effort to achieve equal procedural rights and substantive equality for persons with disabilities in the criminal justice system. We consider what support can help optimise the fitness to stand trial of accused persons with intellectual, cognitive and psychosocial (mental health) disabilities. We refer to this group in shorthand as 'persons with cognitive disabilities'. ${ }^{22}$ Although we

14 Colleen Egan, 'Marlon Noble "Victims" Don't Recall Sex Crimes', The West Australian (online), 18 April $2011<$ https://au.news.yahoo.com/thewest/ wa/a/9212661/marlon-noble-victims-dont-recall-sex-crimes/>.

15 Committee on the Rights of Persons with Disabilities, above n 12, 17 [8.9].

16 Gooding et al, above $\mathrm{n} 8$.

17 Tina Minkowitz, 'Rethinking Criminal Responsibility from a Critical Perspective: The Abolition of Insanity/Incapacity Acquittals and Unfitness to Plead, and Beyond' (2014) 23 Griffith Law Review 434

18 Committee on the Rights of Persons with Disabilities, General Comment No 1: Article 12: Equal Recognition before the Law, 11th sess, UN Doc CRPD/C/GC/1 (11 April 2014) 2 [13]-[15], [29(i)].

19 Law Commission, Unfitness to Plead: Volume 1, Report 364 (2015) 100 [3.171].

20 Anna Arstein-Kerslake et al, 'Human Rights and Unfitness to Plead: The Demands of the Convention on the Rights of Persons with Disabilities' (2017) 17(3) Human Rights Law Review 399.

21 Gooding et al, above $\mathrm{n} 8$.

22 The term 'cognitive disability' does not appear in the CRPD, but is captured with reference to 'mental and intellectual' impairment. We acknowledge that the term is contested, but use it here to refer to persons with a range of disabilities, including intellectual disability, Alzheimer's disease, autism, multiple sclerosis, acquired brain injuries, and so on. See, for example, Anna Arstein-Kerslake, 'An Empowering Dependency: Exploring Support for the Exercise of Legal Capacity' (2014) Scandinavian Journal of Disability Research 1; Eileen Baldry et al, A Predictable and Preventable Path: Aboriginal People with Mental and Cognitive 
focus primarily on persons with cognitive disabilities, the issues are also relevant to others, including people with complex communication needs. ${ }^{23}$ The article covers the legal basis for providing support, with reference to Australian law and the CRPD, and the types of support currently being provided in Australia. We focus on the support needs of those who are 'borderline' fit/unfit, rather than those who, under current legal definitions, are manifestly unfit to stand trial. ${ }^{24}$

\section{Unfitness to Stand Trial Laws and Human Rights Concerns}

The unfitness to stand trial doctrine has been incorporated into statute across Australia. ${ }^{25}$ These laws have three broad features:

1. the assessment of unfitness to stand trial;

2. the testing of the prosecution case following a determination that a person is unfit; and

3. the disposition of the accused.

Typically, unfitness to stand trial determinations can only be made in higher courts. For example, in Victoria, only the County Court and Supreme Court can make unfitness determinations against an adult accused persons. ${ }^{26}$

The common law test for unfitness to stand trial was articulated in the Victorian Supreme Court case of $R v$ Presser. ${ }^{27}$ The 'Presser test', as it is called, has been adopted into legislative provisions across Australia. ${ }^{28}$ The test considers the accused person's ability to:

Disabilities in the Criminal Justice System (University of New South Wales, 2015) 31.

23 For example, people who are deaf and hearing impaired may face similar barriers to participating in criminal proceedings on an equal basis with others. See, for example, $R v$ Fairest [2016] VSC 329.

24 We have considered elsewhere, the law reform that might be required to achieve equal recognition before the law for accused persons in 'hard cases', for whom no amount of individual supports would appear to help the person to actively participate in proceedings. This includes rethinking the very idea that a person might be manifestly unfit to stand trial, and that instead, criminal trials could become universally accessible. See Gooding et al, above n 8; Arstein-Kerslake et al, above $\mathrm{n} 20$.

25 Crimes Act 1900 (ACT) Pt 13; Crimes Act 1914 (Cth) Pt IB Div 6; Mental Health (Forensic Provisions) Act 1900 (NSW) Pt 2; Criminal Code Act (NT) Pt IIA Div 3; Mental Health Act 2000 (Qld) Pt 6; Criminal Law Consolidation Act 1935 (SA) Pt 8A Div 3; Criminal Justice (Mental Impairment) Act 1999 (Tas) Pt 2; Crimes (Mental Impairment and Unfitness to be Tried) Act 1997 (Vic) Pt 2; Criminal Law (Mentally Impaired Accused) Act 1996 (WA).

26 Crimes (Mental Impairment and Unfitness to be Tried) Act 1997 (Vic) ss 4, $5 \mathrm{~A}(1)(\mathrm{a})$.

27 [1958] VR 48

28 See Crimes Act 1900 (ACT) s 311; Crimes Act 1914 (Cth) Pt IB Div 6; Mental Health (Forensic Provisions) Act 1900 (NSW) s 10; Criminal Code Act (NT) s 43J; Mental Health Act 2000 (Qld) ss 256, 257(3); Criminal Law Consolidation 
- understand the nature of the charge;

- plead to the charge and exercise the right of challenge;

- understand the nature of the proceedings;

- follow the course of the proceedings;

- understand the substantial effect of any evidence that may be given in support of the prosecution; and

- make a defence or answer the charge. ${ }^{29}$

The Australian Law Reform Commission raised concerns with the Presser test criteria, criticising the test for failing to take into account the 'possible role of assistance and support for defendants'. ${ }^{30}$

After a person is deemed unfit to stand trial, most jurisdictions hold 'special hearings' in order to test the prosecution case ${ }^{31}$ and ensure proper basis for disposition. ${ }^{32}$ In Subramaniam $v$ The Queen ${ }^{33}$ Gleeson CJ, McHugh, Kirby, Hayne and Callinan JJ stated that the aim of special hearings is:

[F]irst to see that justice is done, as best as it can be in the circumstances, to the accused person and the prosecution. She is put on trial so that a determination can be made of the case against her. The prosecution representing the community has an interest also in seeing that justice be done. A special hearing gives an accused person an opportunity of being found not guilty in which event the charge will cease to hang over her head, and if she requires further treatment that it may be given to her outside the criminal justice system. ${ }^{34}$

Commonwealth law does not provide for a special hearing, and instead, a prima facie case must be made against the accused in order to undertake a disposition of the accused. ${ }^{35}$ In Western Australia and Queensland, tribunals, rather than a court hearing, are held for those deemed unfit to stand trial. ${ }^{36}$

Act 1935 (SA) s 269H; Criminal Justice (Mental Impairment) Act 1999 (Tas) s 8; Crimes (Mental Impairment and Unfitness to be Tried) Act 1997 (Vic) s 6; Criminal Law (Mentally Impaired Accused) Act 1996 (WA) s 9. See also $R v$ Taylor [2014] SASCFC 112, [9] (Stanley J); Kevasarajah v The Queen (1994) 181 CLR 230, 243-245 (Mason CJ, Toohey and Gaudron JJ); $R v$ Gallagher [2012] NSWSC 484, [11] (Beech-Jones J); Berg v DPP [2015] QCA 196, [54] (Flanagan J, Fraser and Morrison JJA agreeing).

29 Kevasarajah v The Queen (1994) 181 CLR 230, 245 (Mason CJ, Toohey and Gaudron JJ).

30 Australian Law Reform Commission, above n 3, 199 [7.35]. This point will be taken up in the next section.

31 Australian Capital Territory, New South Wales, Victoria, South Australia, Tasmania and the Northern Territory.

32 See, for example, Mental Health (Forensic Provisions) Act 1900 (NSW) s 19.

33 (2004) 211 ALR 1.

34 Ibid $12[40]$

35 Crimes Act 1914 (Cth) s 20B(3).

36 In Western Australia, the discretion is exercised - at least nominally - at the vice-regal level, with the Governor acting on the recommendation of the Mentally Impaired Accused Review Board: Criminal Law (Mentally Impaired Accused) Act 1996 (WA) s 24(1). In Queensland, the power to release an individual from a 
A range of concerns have been raised about special hearings and other alternative processes, such as specific tribunals. Of particular concern is that such processes do not afford due process rights to the accused. ${ }^{37}$ Potential disadvantages include not having access to the full range of defences, and having fewer opportunities to test the prosecution's case. ${ }^{38}$ For example, in New South Wales, an accused person is assumed to have pleaded not guilty in relation to the charge, which removes the benefits of entering an early guilty plea in sentence mitigation. ${ }^{39}$ In Western Australia, there are no special hearings that allow accused persons to exercise their right to meet the case against them; the only requirement before making a custody order is that the judge is satisfied it is appropriate to do so considering the 'strength of the evidence against the accused'. ${ }^{40}$ The level of scrutiny required to satisfy the judicial officer is lower than in normal criminal trials. ${ }^{41}$

Disposition made by courts for those found unfit to stand trial vary between jurisdictions. Most permit a court or tribunal to elect between acquittal, a 'community-based' supervision order, or a custodial order. ${ }^{42}$ Non-custodial supervision orders typically follow less serious charges and usually require residence in a secure, non-prison setting, or a highly restrictive disability service setting. An order may also be varied from non-custodial to custodial if a person is deemed to pose a danger to others or because those subject to an order breach its conditions or commit an offence. In the Northern Territory, those subject to supervision orders face a high likelihood that the order will become custodial at a later stage, given compliance requirements are often complex and may be difficult to satisfy for persons with cognitive disabilities. ${ }^{43}$

custodial order rests with an administrative tribunal - the Mental Health Review Tribunal: Mental Health Act 2000 (Qld) ss 203(1), 207, 288, 293.

37 See Mindy Sotiri, Patrick McGee and Eileen Baldry, The Imprisonment and Indefinite Detention of Indigenous Australians with a Cognitive Impairment (National Justice Chief Executive Officers Working Group, 2012); Eileen Baldry, 'Disability at the Margins: Limits of the Law' (2014) 23(3) Griffith Law Review 370; Arstein-Kerslake et al, above n 20; Gooding et al, above n 8.

38 Arstein-Kerslake et al, above n 20; Gooding et al, above n 8.

39 Kerri Eagle and Andrew Ellis, "The Widening Net of Preventative Detention and the Unfit for Trial' (2016) 90(3) Australian Law Journal 174.

40 Criminal Law (Mentally Impaired Accused) Act 1996 (WA) ss 16(6)(a), 19(5)(a); Western Australia v Tax [2010] WASC 208, [3]; Western Australia v Stubley (No 2) [2011] WASC 292, [19].

41 Western Australia v Tax [2010] WASC 208, [3]; Western Australia v Stubley (No 2) [2011] WASC 292, [19].

42 Crimes (Mental Impairment and Unfitness to be Tried) Act 1997 (Vic) s 26(2)(b); Criminal Law Consolidation Act 1935 (SA) Pt 8A Div 4; Criminal Law (Mentally Impaired Accused) Act 1996 (WA) s 22; Criminal Code Act 1983 (NT) s 43ZA(1); Criminal Justice (Mental Impairment) Act 1999 (Tas) s 29A; Mental Health Act 2000 (Qld) s 275; Crimes Act 1900 (ACT) ss 323(3), 308, 335(2); Mental Health Act 2015 (ACT) ss 108(1)(c), 101(1)(c); Mental Health (Forensic Provisions) Act 1990 (NSW) s 23(2). See Gooding et al, above n 8, 22.

43 Jonathan Hunyor and Michelle Swift, 'A Judge Short of a Full Bench: Mental Impairment and Fitness to Plead in the NT Criminal Legal System' (Paper 
Forms of custodial detention differ considerably between jurisdictions, but in all jurisdictions, the potential for disadvantage compared to typical sentencing remains. One of the most obvious of these is in Western Australia, where those found unfit to stand trial face detention 'until released by an order of the Governor'. ${ }^{44}$ In Queensland, similar discretionary power is granted to a mental health tribunal in determining the length of a custodial order. ${ }^{45}$ In other jurisdictions, which have abolished the use of 'governor's pleasure' detention, ${ }^{46}$ a custodial order operates more like a sentence imposed after conviction and expires on a pre-determined date. ${ }^{47}$ Nevertheless, even in these jurisdictions, those deemed unfit are essentially detained indefinitely, and there are few, if any, statutory limits on the period of detention or supervision. For example, in the Northern Territory and Victoria, although the court is required to set a 'nominal term' for the purposes of a review, ${ }^{48}$ supervision orders remain indefinite. ${ }^{49}$ This is despite nominal terms being designed, in part, to safeguard against indefinite and arbitrary detention by enforcing regular reviews. ${ }^{50}$ Nominal terms are intended to match the term if a conviction had been made, and the review process considers whether the person poses a serious risk to the public. If the person is believed to pose such a risk, he or she is further detained. ${ }^{51}$ In Victoria, courts are obliged to impose nominal terms to correspond with the maximum penalty for the offence, which raises concerns about equality given it is unusual to have the maximum sentence imposed if convicted ${ }^{52}$ and the standardised approach offers little scope to tailor a nominal term to an individual's circumstances. ${ }^{53}$

A range of government and non-government organisations have raised concerns about the indefinite detention of people with cognitive disabilities found unfit to stand trial. ${ }^{54}$ Several high-profile cases, such as that of Marlon Noble, have brought attention to possible miscarriages of justice.

presented at the Criminal Lawyers Association Northern Territory Conference, Bali, 30 June 2011) 22; Victorian Law Reform Commission, Review of the Crimes (Mental Impairment and Unfitness to be Tried) Act 1997, Report 28 (2014) xxxv. Criminal Law (Mentally Impaired Accused) Act 1996 (WA) s 24(1).

$45 \quad$ Mental Health Act 2000 (Qld) ss 203(1), 207, 288, 293.

46 In Victoria, for example, it was abandoned with the introduction of the Crimes (Mental Impairment and Unfitness to be Tried) Act 1997 (Vic). See also Ian Freckelton, 'Indefinite Detention in Australia: The Ongoing Risk of Governor's Pleasure Detention' (2014) 21 Psychiatry, Psychology and Law 469, 473.

47 See, for example, New South Wales and South Australia.

48 Criminal Code Act 1983 (NT) ss 43ZG, 28. The nominal terms are generally equivalent to the maximum term of imprisonment available for the offence. See Victorian Law Reform Commission, above n 43.

49 Crimes (Mental Impairment and Unfitness to be Tried Act) 1997 (Vic) s 27; Criminal Code Act 1983 (NT) Sch 1, s 43ZC.

50 Victorian Law Reform Commission, above n 43, 361 [10.118].

51 Criminal Code Act 1983 (NT) s 43ZG(6); Crimes (Mental Impairment and Unfitness to be Tried) Act 1997 (Vic) s 35(3)(a)(i).

52 Victorian Law Reform Commission, above n 43, 364 [10.127].

53 Ibid.

54 See Sotiri, McGee and Baldry, above n 37; Baldry, above n 37. 
For example, in 2015, the Australian Broadcasting Commission reported that a 14-year-old Indigenous teenager from Western Australia, 'Jason', was found unfit to stand trial for a charge of manslaughter but was nevertheless detained for over 11 years. ${ }^{55}$ In contrast, equivalent manslaughter cases that have gone to trial have reportedly led to sentences of four to eight years. ${ }^{56}$ In 2014, the Australian Human Rights Commission reported that a person had been found unfit to plead and placed in remand for four months for stealing $\$ 50 .{ }^{57}$

The best method to implement CRPD requirements in unfitness to stand trial laws remains unclear. ${ }^{58}$ However, there is a general consensus on the value of a full trial, and the need to improve court accessibility. ${ }^{59}$ The Law Commission of England and Wales summarises the value of a full trial, when it writes:

We consider that full trial is best not just for the defendant, but also for those affected by an offence and society more generally. This is because the full criminal process engages fair trial guarantees for all those involved ... and allows robust and transparent analysis of all the elements of the offence and any defence advanced. It also offers the broadest range of outcomes in terms of sentence and other ancillary orders. ${ }^{60}$

The New South Wales Law Reform Commission expressed a similar sentiment, and recommended statutory provisions, which "provide that the court consider whether modifications to the trial process can be made, or assistance be provided, to make it possible for the defendant to participate effectively in the trial'. ${ }^{61}$

\section{A Shifting the Focus to Support}

All major Australian law reform inquiries to consider unfitness to stand trial laws recommended the introduction of formal support measures for

55 Australian Broadcasting Corporation, "Urgent Need" for Law Change as Mentally-Impaired Accused Detained Indefinitely, WA Chief Justice Wayne Martin Says', 7.30 (online), 10 July $2015<$ http://www.abc.net.au/news/2015-07-10/ push-for-mentally-impaired-accused-law-change-in-wa/6611010>.

56 Nicolas Perpitch, 'Indefinite Jailing: Call for Review as Indigenous Driver Involved in Fatal Crash Remains in Prison', ABC News (online), 17 September 2014 <http://www.abc.net.au/news/2014-09-16/call -for-review-of-incarceration-of-former-teen-fatal-driver/5748090>.

57 Australian Human Rights Commission, Equal Before the Law: Towards Disability Justice Strategies (February 2014) 26.

58 CRPD Art 14(1)(b); Committee on the Rights of Persons with Disabilities, above n 9, 2 [8]-[9]; Committee on the Rights of Persons with Disabilities, Guidelines on Article 14 of the Convention on the Rights of Persons with Disabilities: The Right to Liberty and Security of Persons with Disabilities, 14th sess (2015) 2, 6 [20].

59 See New South Wales Law Reform Commission, People with Cognitive and Mental Health Impairments in the Criminal Justice System: Criminal Responsibility and Consequences, Report 138 (2013) xvi [0.10]; Law Commission, above n 19, 3 [1.11]; Victorian Law Reform Commission, above n 43, 89 [3.124].

60 Law Commission, above n 19, 3 [1.11].

61 New South Wales Law Reform Commission, above n 59. 
accused persons with cognitive disabilities. ${ }^{62}$ For example, the Australian Law Reform Commission recommended a reformulation of the Presser test 'to focus on whether, and to what extent, a person can be supported to play their role in the justice system, rather than on whether they have capacity to play such a role at all'. ${ }^{63}$ Similarly, the Victorian Law Reform Commission, recommended amendments to the Crimes (Mental Impairment and Unfitness to be Tried) Act 1997 (Vic) to ensure that, when a court considers the accused's fitness to stand trial, it must consider whether the trial process could be appropriately modified ${ }^{64}$ - a recommendation that appears to have been included in a Bill introduced to Victorian Parliament at the time of writing. ${ }^{65}$ The Victorian Law Reform Commission noted that ' $[\mathrm{t}]$ he importance of support measures in the unfitness to stand trial process was one of the strongest themes to come out of the Commission's review'. ${ }^{66}$ In Western Australia, the Department of the Attorney-General in Western Australia recommended introducing a separate provision to mandate support for those suspected of being unfit to stand trial. ${ }^{67}$

The call for accessibility and support measures for people with disabilities in the criminal justice system has been echoed by statutory bodies and non-government organisations, particularly disabled peoples' organisations. ${ }^{68}$ The Australian Human Rights Commission reported that access to justice for people with disabilities is a 'significant issue in every jurisdiction in Australia'. ${ }^{69}$ The Commission noted that lack of support was among the major barriers to justice for people with disabilities. ${ }^{70}$ It stated that it is extremely concerned about arrangements and

62 See New South Wales Law Reform Commission, above n 59, Recommendation 2.2; Victorian Law Reform Commission, above n 43, 89 [3.124]-[3.125]; Australian Law Reform Commission, above n 3, 199-200 [7.35]-[7.40], Recommendation 7-1; Department of the Attorney-General (WA), Review of the Criminal Law (Mentally Impaired Accused) Act 1998, Final Report (2016) 73, 74.

63 Australian Law Reform Commission, above n 3, 192 [7.4] (emphasis added).

64 Victorian Law Reform Commission, above n 43, 87 [3.116].

65 Crimes (Mental Impairment and Unfitness to be Tried) Amendment Bill 2016 (Vic) ss 3(C)(2)(d), 8(3)(c).

66 Victorian Law Reform Commission, above n 43, 89 [3.124]-[3.125].

67 Department of the Attorney-General, above n 62 [118]-[119].

68 See, for example, People with Disabilities Australia, Access to Justice <http:// www.pwd.org.au/admin/access-to-justice.html>; First Peoples Disability Network, 'Aboriginal and Torres Strait Islander Perspectives on the Recurrent and Indefinite Detention of People with Cognitive and Psychiatric Impairment: A Submission to the Senate Inquiry on the Indefinite Detention of People with Cognitive and Psychiatric Impairment', April $2016<$ http://fpdn.org.au/>. For an excellent account of professional stakeholder views of human rights issues concerning unfitness to stand trial laws, mostly concerning those already found unfit to stand trial, see P Keyzer and D O'Donovan, 'Imprisonment of Indigenous People with Cognitive Impairment: What Do Professional Stakeholders Think? What Might Human Rights-Compliant Legislation Look Like?' (2016) 8(22) Indigenous Law Bulletin 17.

69 Australian Human Rights Commission, above n 57, 1.

70 Ibid 8. 
processes for people with disabilities deemed unfit to plead', ${ }^{71}$ including 'inadequate safeguards and access to supports to ensure effective access to justice'. ${ }^{72}$

Government policy appears somewhat responsive to these calls, as evidenced by the National Disability Strategy policy area of 'rights protection, justice, and legislation'. ${ }^{73}$ Policy Direction 5 of the Strategy seeks to 'support people with disability with heightened vulnerabilities in any contacts with the criminal justice system, with an emphasis on early identification, diversion and support', including '[e]nsur[ing] supported decision-making safeguards for those people who need them'. ${ }^{74}$

However, despite these high-profile recommendations and policy directives, it appears that few, if any, supports for accused persons with cognitive disabilities who are at risk of being deemed unfit to stand trial, have been implemented systemically in any Australian jurisdiction. Hence, there is a need to develop and evaluate formalised support for accused persons at risk of being unable to participate in proceedings against them.

\section{B The CRPD and the Positive Obligation to Provide Support to Persons with Disabilities}

The shift in focus to support has been partly driven by the CRPD. Article 5 of the CRPD requires states parties to 'guarantee to persons with disabilities equal and effective legal protection against discrimination on all grounds', ${ }^{75}$ which includes ensuring the provision of 'reasonable accommodation'. ${ }^{76}$ Reasonable accommodation is defined as:

$[\mathrm{N}]$ ecessary and appropriate modification and adjustments not imposing a disproportionate or undue burden, where needed in a particular case, to ensure to persons with disabilities the enjoyment or exercise on an equal basis with others of all human rights and fundamental freedoms. ${ }^{77}$

Article 13 specifically concerns access to justice on an equal basis with all others, 'including through the provision of procedural and ageappropriate accommodations' and training for judicial staff. ${ }^{78}$ Support should 'facilitate [persons with disabilities'] effective role as direct and

\footnotetext{
$71 \quad$ Ibid 26.

72 Ibid.

73 Gwyneth Llewellyn, Report of Audit of Disability Research in Australia Centre for Disability Research and Policy (Faculty of Health Sciences, University of Sydney, 2014) 7 .

74 Ibid 41.

75 CRPD Art 5.

76 Rosemary Kayess and Phillip French, 'Out of Darkness into Light? Introducing the Convention on the Rights of Persons with Disabilities' (2008) 8(1) Human Rights Law Review 1.

77 CRPD Art 5.

78 Ibid Art 13(1) (emphasis added).
} 
indirect participants, including as witnesses, in all legal proceedings' ${ }^{79}$ Failure to provide such accommodations may amount to discrimination under Art 5. ${ }^{80}$

Article 9 provides a generalised right to accessibility, and directs states parties to 'take appropriate measures to ensure to persons with disabilities access, on an equal basis with others, to the physical environment ... to information and communications ... and to other facilities and services open or provided to the public'. This includes an emphasis on measures, "which shall include the identification and elimination of obstacles and barriers to accessibility'. ${ }^{81}$ This type of support can be especially important in courtrooms, where use of assistance, such as supporters acting as 'interpreters' of court proceedings, or plain language materials, may be provided. If these accessible mechanisms are not available for persons with intellectual disabilities, Arts 5, 9 and 13 may be violated.

Article 12 refers to the right to equal recognition before the law. Article 12 requires states parties to 'take appropriate measures to provide access by persons with disabilities to the support they may require in exercising their legal capacity' ${ }^{82}$ The CRPD Committee has stated that 'the recognition of the right to legal capacity is essential for access to justice in many respects' ${ }^{83}$ In addition, the CRPD Committee indicates that the discriminatory denial of legal capacity and denial of the right to support in the exercise of legal capacity, which has 'the purpose or effect of interfering with the right of persons with disabilities to equal recognition before the law' would violate Arts 5 and 12 of the CRPD. ${ }^{84}$ Article 12 was a key driver of the Australian Law Reform Commission report, Equality, Capacity and Disability in Commonwealth Laws, and its recommendation to mandate support for accused with cognitive disabilities. ${ }^{85}$

There is a range of possible supports for accused persons with cognitive disabilities that can improve courtroom accessibility. The needs of specific individuals with cognitive disabilities charged with crimes will vary, but effective supports may include:

\section{$79 \quad$ Ibid Art 13.}

80 Ibid Art 2. See also Stephanie Ortoleva, 'Inaccessible Justice: Human Rights, Persons with Disabilities and the Legal System' (2011) 17 ILSA Journal of International \& Comparative Law 282; Eilionóir Flynn, Disabled Justice? Access to Justice and the UN Convention on the Rights of Persons with Disabilities (Ashgate, 2015) 11-16.

81 CRPD Art 9.

82 Ibid Art 12(2)(3) (emphasis added).

83 Committee on the Rights of Persons with Disabilities, above n 18, 10 [38].

84 Ibid 8 [32].

85 Australian Law Reform Commission, above n 3. Article 12 is also the key article to bring into question the very existence of unfitness to plead laws, given it promotes equal recognition before the law and unfitness to plead laws create separate - and seemingly lesser - procedural rights for people with cognitive disabilities. See Arstein-Kerslake et al, above n 20. 
- additional breaks in court proceedings; ${ }^{86}$

- counsel explaining court processes to the accused person in an accessible way, and ensuring language is accessible or slowed to allow interpretation and/or explanation; ${ }^{87}$

- providing a support person, including a family member or a more formal support person, such as court-based supporters under 'special witness declarations'; 88

- 'easy English' summaries of trial proceedings including provision of dot-point summaries at the end of each court day; ${ }^{89}$

- video testimony for those who may find the courtroom environment distressing or confusing; ${ }^{90}$

- educational sessions/programs for accused who may be considered fit to stand trial following education; ${ }^{91}$ and

- modifying courtrooms in a variety of ways to make them more accessible. ${ }^{92}$

As the next section will show, this list of support measures has been drawn from statute and case law, and from proposals by law reform bodies and others.

\section{Support Measures under CurRent Statute ANd CASE LaW}

Current statute and case law provide grounds for providing procedural accommodations and court accessibility measures for those at risk of being deemed unfit to stand trial. However, there is little in the way of enforceable mechanisms that impose a duty on courts to ensure accessibility. Although courts are open to modifying proceedings to assist accused persons with disabilities, the extent to which this occurs depends upon the discretion of individual courts. This discretionary power provides an important degree of flexibility for each court to pursue creative modifications and accessibility measures depending on each case. However, this flexibility does not provide strong grounds from which to claim rights to

86 See, for example, GAE v Western Australia [2011] EWCA Crim 443; R v JG [2014] ACTSC 120, [14].

87 See, for example, $R v$ JG [2014] SASCFC 112; $R v$ Muller [2013] ACTSC 154.

88 See, for example, Crimes Act 1914 (Cth) s 15YAB; Evidence (Children and Special Witnesses) Act 2001 (Tas) s 8; Evidence Act 1977 (Qld) s 21A(1); Evidence Act 1906 (WA) s 106R; Evidence Act 1995 (NSW) s 26; Evidence Act 2008 (Vic) ss 11(1), 26; Evidence Act 1929 (SA) ss 13, 25; Evidence Act 2011 (ACT) s 26; Evidence (National Uniform Legislation) Act 2011 (NT) ss 11, 26; Domestic and Family Violence Act 2007 (NT) s 104.

89 See, for example, $R v$ Fairest [2016] VSC 329.

90 See, for example, GAE $v$ Western Australia [2011] EWCA Crim 443.

91 See, for example, $R v$ Fairest [2016] VSC 329.

92 For more examples see Flynn, above n 80, 83-116; Arlene S Kanter, The Development of Disability Rights under International Law: From Charity to Human Rights (Routledge, 2014) 221-235. 
accessibility, procedural accommodations and support to exercise legal capacity.

\section{A Supports in Legislation for Accused Persons at Risk of Being Found Unfit to Stand Trial}

Across Australia, some areas of statute law provide grounds for offering procedural accommodations to accused persons with cognitive disabilities at risk of being deemed unfit to stand trial.

The law of evidence provides one such avenue. For example, evidence law in each jurisdiction provides powers to control the questioning of witnesses and oversee the conduct of the proceedings more generally. ${ }^{93}$ Judicial officers have a general power to control the conduct of proceedings, which can provide discretion to make adjustments and introduce measures to allow people with disability to participate in proceedings. In Victoria, the Disability Access Bench Book recommends a range of ways judicial officers can refer to the Evidence Act 2008 (Vic) to improve the accessibility of court proceedings. ${ }^{94}$ These measures include the use of pre-recording and closed circuit television in a remote witness facility, ${ }^{95}$ and making adjustments for witnesses who cannot hear or speak, such as time allowances for the witness to respond to questions and physical adjustments. ${ }^{96}$ The Bench Book resource was published by the Judicial College of Victoria, in partnership with the Victorian Equal Opportunity and Human Rights Commission, and provides information and guidance for judicial officers in making the Victorian court system accessible for people with various disabilities. ${ }^{97}$ Many of the recommendations would be applicable to laws of evidence and criminal procedure across Australia. The Bench Book offers practical recommendations for directing hearings and adjusting communication where people with a disability are complainants, defendants, witnesses or otherwise participating in hearings. ${ }^{98}$ With regards to the CRPD, this resource is a step in the direction of Art 13(2), which requires Australia to "promote appropriate training for those working in the field of administration of justice, including police and prison staff' in order to ensure effective access to justice for persons with disabilities. ${ }^{99}$ At this stage, it is unclear to what extent many of these provisions

93 See, for example, Crimes Act 1914 (Cth) s 15YAB; Evidence (Children and Special Witnesses) Act 2001 (Tas) s 8; Evidence Act 1977 (Qld) s 21A(1); Evidence Act 1906 (WA) s 106R; Evidence Act 1995 (NSW) s 26; Evidence Act 2008 (Vic) ss 11(1), 26; Evidence Act 1929 (SA) ss 13, 25; Evidence Act 2011 (ACT) s 26; Evidence (National Uniform Legislation) Act 2011 (NT) ss 11, 26; Domestic and Family Violence Act 2007 (NT) s 104.

94 See, for example, Judicial College of Victoria, Disability Access Bench Book (2016) ss $3.3,5.6 .1,5.7,5.9,5.10,5.19,5.20 .1,5.20 .2,5.21$.

$95 \quad$ Ibid s 5.13 .

96 Ibid s 5.10.

97 Ibid s 1.

98 Ibid.

99 CRPD Art 13(2). 
are being used, or to what extent the different measures are allowing people with cognitive disabilities the support they need to participate in proceedings. In the following section, we examine case law, to gain a sense of the extent to which similar mechanisms are used, particularly in cases where a person risks being found unfit to stand trial.

Another relevant statutory measure in all jurisdictions is the appointment of a support person. ${ }^{100}$ For example, the West Australian Attorney-General's office advised courts to consider appointing a support person via 'special witness declarations' pursuant to s $106 \mathrm{R}$ of the Evidence Act 1906 (WA). ${ }^{101}$ Alternatively, the accused person can be provided with a communication assistant when giving evidence. ${ }^{102}$ The 'special witness' category is not limited to those with cognitive disabilities, and the criteria require that the individual is unlikely to be able to give evidence in the ordinary manner due to disability, intimidation, distress or emotional trauma. ${ }^{103}$ Often, communication assistants are directed to witnesses rather than accused persons, and only while giving evidence. In New South Wales, a 'vulnerable person' under the meaning of the Criminal Procedure Act 1986 (NSW) refers to a witness (including a defendant) who is a 'child or a cognitively impaired person'. ${ }^{104}$ Such a person has the right to request the presence of a 'supportive person', ${ }^{105}$ who may be a parent, relative, friend, associate or guardian. ${ }^{106}$ Setting aside possible concerns with conceptualising cognitively impaired persons as vulnerable and in the same category as children, the 'supportive person' may act as an interpreter, or offer reassurance, explanations, and other forms of support. Once again, however, the support only applies to a defendant while he or she is in the witness box. In addition, it is unclear whether this mechanism has been used in proceedings to any significant extent. ${ }^{107}$ Phoebe Bowden and colleagues argue that the laws seem to allow for a broad scope that goes beyond 'emotional support ... [and instead includes] assisting the witnesses' comprehension and communication of evidence'. ${ }^{108}$ However, the New South Wales Government seems to view the supporter's role, at least in the witness support context, as being confined to emotional support. ${ }^{109}$

100 See above $\mathrm{n} 88$.

101 Evidence Act 1906 (WA) s 106R; Department of the Attorney General, above n 62, [118]-[119].

102 Department of the Attorney-General, above n 62, [119].

103 Ibid.

104 Criminal Procedure Act 1986 (NSW) s 306M.

105 Ibid s 306ZK(2).

106 Ibid s 306ZK(3)(a).

107 Phoebe Bowden, Terese Henning and David Plater, 'Balancing Fairness to Victims, Society and Defendants in the Cross-Examination of Vulnerable Witnesses: An Impossible Triangulation?' (2014) 37(3) Melbourne University Law Review 539, 574.

108 Ibid 574.

109 Victim Services, Justice Journey Court Preparation Guide (Department of Justice, 2012) $23<\mathrm{http}: / /$ www.victimsservices.justice.nsw.gov.au/Documents/ fs36_workers-guide.pdf $>$. 
This constraint on the type of support that can be provided further limits the potential for procedural accommodation via this legislative provision, making it seem like it holds rather narrow scope to optimise an individual's fitness to stand trial.

The South Australian Parliament introduced a number of accommodations for 'vulnerable witnesses', including those with a 'mental disability'. ${ }^{110}$ The Statutes Amendment (Vulnerable Witnesses) Act 2015 (SA) (Vulnerable Witnesses Act) created a statutory entitlement to a communication assistant, ${ }^{111}$ and expanded the classes of support people permitted to provide emotional support. ${ }^{12}$ While communication assistance can be provided by anyone the court deems suitable, ${ }^{113}$ there is a specific provision for a more formalised 'communication partner', which is an individual approved by the Minister to provide assistance to witnesses. ${ }^{114}$ This unusual provision would seem to offer a more robust mechanism for support in line with Art 13(1) than elsewhere in Australian law. Interestingly, however, it is anticipated at the time of writing that communication partners will be volunteers, even as they are operating under a formal, specialist scheme. ${ }^{115}$ The voluntary nature of the support has caused controversy given volunteers will not necessarily be available to provide support, ${ }^{116}$ and may also reinforce the charity-based view of disability, which the CRPD was specifically designed to displace. ${ }^{117}$ This use of volunteers is paradoxical, given the CRPD was a key driver of the suite of reforms South Australia introduced along with the Vulnerable Witnesses Act. ${ }^{118}$ Further, and once again, the communication assistant role is limited to assistance while the defendant is giving evidence. This may limit its effectiveness in avoiding findings of unfitness to plead, because support is likely to be needed at a much earlier stage; for example, in pre-trial support that could include assessing support requirements, arranging various support people, and preparing the accused person for court proceedings.

$110 \quad$ Evidence Act 1929 (SA) s 4 (definition of 'vulnerable witness').

111 Ibid s 13A(5A).

112 Ibid s 13A(5).

113 Ibid s 13A(5A)(a)(i).

114 Ibid s 13A(5A)(a)(i).

115 South Australia, Parliamentary Debates, House of Assembly, 6 May 2015, 1038 (John Rau, Attorney-General).

116 Alexia Attwood, 'Disability Advocates Unhappy with Plan to Use Volunteers in Courts; Experts Give "Consistency", $A B C$ News (online), 15 December $2015<$ http://www.abc.net.au/news/2015-12-15/disabilityadvocates-unhappy-with-courts-plan-for-volunteer-help/7030666>.

117 Statement by Louise Arbour, UN High Commissioner for Human Rights on the Ad Hoc Committee's Adoption of the International Convention on the Rights of Persons with Disabilities, 5 December $2006<\mathrm{http} / /$ www.un.org/esa/socdev/ enable/rights/ahc8hrcmsg.htm>.

118 Government of South Australia, Disability Justice Plan 2014-2017 (nd) $2<$ https:// www.agd.sa.gov.au/projects-and-consultations/disability-justice-plan>. 
The communication assistant role in South Australia was modelled on the British registered intermediary scheme, ${ }^{119}$ which provides for courtappointed experts who facilitate the flow of information to and from the witnesses with disabilities during the giving of evidence. The registered intermediary is an independent and impartial officer of the court; their paramount duty is owed to the court. ${ }^{120}$ There are moves to introduce similar court intermediaries in Tasmania. ${ }^{121}$ In New South Wales, the intermediary scheme was used as the basis for the 'Children's Champions' program, ${ }^{122}$ in which alleged child victims of sexual assault are assisted in courts. ${ }^{123}$ These moves highlight a trend in which governments are introducing formal support roles in courts, which may be used or at least transferred to the context of assisting accused persons with disabilities at risk of being deemed unfit to stand trial. However, these measures are largely directed toward witnesses, which suggests an emphasis on assisting victims rather than accused persons. In addition, this assistance is often couched in terms of vulnerability, protection, welfare and charitybased concerns, which does not suggest a strong equality and rights-based framework for establishing minimum guarantees to access to justice and equal recognition before the law.

On the other hand, it is noteworthy that these legislative measures are drawn from mainstream procedures of law, rather than separate processes, such as special hearings. As previously discussed, the CRPD promotes a shift away from 'adaptation and specialized design' ${ }^{124}$ and toward equality and 'universalism'. ${ }^{125}$ This requirement has been characterised by

119 Youth Justice and Criminal Evidence Act 1999 (UK) c 23, s 16.

120 Ministry of Justice, Registered Intermediary Procedural Guidance Manual (2015) 9.

121 Tasmania Law Reform Institute, Facilitating Equal Access to Justice: An Intermediary/Communication Assistant Scheme for Tasmania?, Issues Paper 22 (2016).

122 Department of Justice (NSW), 'Victims Services Now Seeking Children's Champions' (Media Release, 3 December 2015) <http://www.justice.nsw.gov. au/Pages/media-news/news/2015/victims-services-seeking-witness-intermediaries.aspx>. See also Criminal Procedure Amendment (Children's Champions) Regulation 2016 (NSW); Criminal Procedure Amendment (Child Sexual Offence Evidence Pilot) Bill 2015 (NSW) (Second Reading) <https://www.parliament.nsw. gov.au/bills/Pages/bill-details.aspx?pk=3199>.

123 It is interesting to note that, during the consultation process, Legal Aid New South Wales preferred the term 'witness intermediary' to 'Children's Champion'. They noted that 'as an intermediary is not the child's advocate or support person, they should not be termed "champion" ... this may encourage misconceptions about the role of the intermediary'. They also advocated for the inclusion of defendants in the scheme. These recommendations were not adopted. See Legal Aid New South Wales, Submission to Department of Justice, Consultation Paper: Children's Champions and Pre-recording of Evidence July 2015, August 2015, $8<$ http://www.legalaid.nsw.gov.au/_data/assets/pdf_file/0005/22469/ChildrensChampions-and-pre-recording-of-evidence-20150811.pdf $>$.

124 CRPD Art 2.

125 Gerard Quinn, 'A Short Guide to the United Nations Convention on the Rights of Persons with Disabilities' in Gerard Quinn and Lisa Waddington (eds), European 
Rosemary Kayess and Phillip French as the 'radical modification of the social norm to reflect human diversity'. ${ }^{126}$ Resources such as the Disability Access Bench Book promote a shift in this direction by pointing to ways that existing statutory measures for all people can be used specifically to improve accessibility for people with disabilities. However, the extent to which these measures are being used by courts is unclear, though it appears limited. As we argue in the next section, the case law paints a picture of the ad hoc use of supports provided for in legislation to assist accused persons at risk of being deemed unfit to stand trial.

\section{B Supports in Case Law}

Case law highlights the willingness of some courts to assist accused persons to optimise fitness to stand trial. In England, Thomas LJ observed in $R v$ Walls that:

Plainly consideration should be given to the use of ... ways in which the characteristics of a defendant ... can be accommodated with the trial process so that his limitations can be understood by the jury, before a court takes the very significant step of embarking on a trial of fitness to plead. ${ }^{127}$

In Australia, statute law clearly provides similar scope to assist accused persons with disabilities, but again, such assistance appears inconsistently across jurisdictions.

In $G A E v$ Western Australia, ${ }^{128}$ the expert witnesses submitted that the accused had 'poorly defined cognitive impairment' 129 and 'mental impairment', ${ }^{130}$ and the court allowed for the use of regular breaks, a closed-circuit television room so the person could provide a statement, and the assistance of a family member in communication following a 'special witness declaration'. ${ }^{131}$ These supports were considered appropriate safeguards that enabled the defendant to participate in proceedings. As a result, the accused was found to be fit to stand trial. ${ }^{132}$

In $R v$ Taylor, ${ }^{133}$ the accused had an intellectual disability and the court ruled that he had demonstrated fitness to stand trial through his conduct and engagement with the processes when court proceedings were properly explained to him in simple terms. ${ }^{134}$ In addition, the court found that the expert opinion (which argued that the person was unfit to stand trial) could be disregarded. ${ }^{135}$ The court emphasised the role of the counsel

Yearbook on Disability Law: Volume 1 (Intersentia, 2009) 89; Kayess and French, above $\mathrm{n} 76,10$.

126 Kayess and French, above n 76, 10.

127 [2011] EWCA Crim 443.

128 [2015] WADC 5.

129 Ibid [11].

130 Ibid [14].

131 Evidence Act 1906 (WA) s 106R.

132 GAE v Western Australia [2015] WADC 5, [42].

133 [2014] SASCFC 112.

134 Ibid [39].

135 Ibid [39]. 
to appropriately explain the trial process to the accused person, including the nature of the charges, relevant procedural rights and the significance of challenging potential jurors. ${ }^{136}$

In $R v J G,{ }^{137}$ the existence of appropriate supports for the accused prompted the court to conclude that JG, whom the court determined had a 'mild intellectual impairment', was fit to stand trial. These supports included taking regular breaks to allow the accused to consult with counsel, showing the willingness of the court to engage with adapted processes to ensure proper supports are provided, including the court intervening to 'insist upon counsel using short, simple questions during the trial process'. 138

In contrast to these examples of courts successfully providing support, some courts have been unable, and in some cases unwilling, to provide support that may have assisted the accused to reach the threshold of fitness to stand trial. For example, in Peters $v$ Police, the accused person, an Indigenous man from a remote Aboriginal community, was identified as having an acquired brain injury. ${ }^{139}$ There was no reference by the court to potential support measures to assist the accused. Identification of the extent of his brain injury was ruled out as it would be 'exceptionally difficult' due to his residence in a remote community, and the man's lack of English skills appeared to be treated as a partial justification for the psychologist's recommendation of unfitness. ${ }^{140}$

In $R v$ Muller, ${ }^{141}$ the court decided that there was nothing that could be done by way of supports to improve the accused's ability to participate effectively. However, it was noted that at most points of the trial the 'accused's intellectual deficits could be accommodated by taking breaks so that his counsel could explain to him what was occurring, ensure he understood the evidence and its significance and take instructions from him'. Ultimately, however, this option was dismissed as 'a potentially laborious process'. ${ }^{142}$

In $R v$ Mathews, ${ }^{143}$ the self-represented accused person was a man with an acquired brain injury who reported experiencing fatigue and difficulty cross-examining witnesses. ${ }^{144}$ At trial he notified the court of support needs, which he identified as taking regular breaks and having his two dogs accompany him in the courtroom, both of which were accommodated. ${ }^{145}$ On appeal the accused invoked the CRPD and submitted that his human rights were violated because the trial judge failed to accommodate

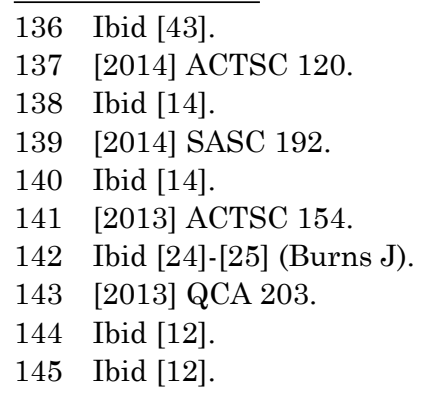


support needs that the accused himself could not identify (but which, he claimed, the court had a duty to discover). This argument was not accepted and the Queensland Court of Appeal determined that the onus lay with the accused to identify and request support measures, which in this instance were met by the court. The question of the accused's special needs was held to be separate from the issue of his fitness to stand trial. ${ }^{146}$

$R v$ Fairest $^{147}$ involved three co-accused persons who were noted to be 'profoundly deaf' and to have cognitive disabilities. ${ }^{148}$ When concerns were raised about the capacity of one of the co-accused to 'follow the course of a trial', the court suggested that he could be regarded as doing so if 'compensatory strategies [were permitted] ... such as his counsel explaining important material to him during breaks in proceedings', ${ }^{149}$ or where easy-English summaries in dot-point were provided. ${ }^{150}$ The accused was later found unfit, despite the proposed accommodations. Counsel for one of the co-accused submitted to the court that where a judge thought an accused could become fit following completion of an education program, then s 12(2)(d) of the Crimes (Mental Impairment and Unfitness to be Tried) Act 1997 (Vic) might apply. This section of the Act gives discretion for the trial judge to adjourn the matter if the judge determines that the accused is likely to become fit within the next 12 months'. ${ }^{151}$ The court found it unnecessary to consider this question but interestingly, in obiter dicta, indicated that the Act did not confer such a power. This was because such power is contingent on first determining that the accused is likely to become fit within the next 12 months before making 'any such order the judge thinks appropriate'. ${ }^{152}$ The proposed accommodation of an education program appears to have been largely dismissed because such a program does not currently exist.

The case law highlighted above indicates that support measures can be used across Australia, but in a way that leaves considerable discretion with courts and few, if any, binding duties to ensure accessibility. In the terms of the Victorian Law Reform Commission:

Although it is currently open to courts and experts to consider the availability of support measures in determinations of unfitness to stand trial, it is evident from the input received that these are not necessarily considered, provided or available in all cases ... The current system is dependent on prosecutorial discretion and the individual decisions of lawyers. The lack of guidelines or judicial oversight results in a process that has been described as 'ad hoc'. ${ }^{153}$

\footnotetext{
146 Ibid [29].

147 [2016] VSC 329.

148 Ibid [2].

149 Ibid [35].

150 Ibid [36]. 'Easy English' refers to written English that is more accessible for people who have difficulty reading and understanding written information.

151 Crimes (Mental Impairment and Unfitness to be Tried) Act 1997 (Vic) s 12(2)(d).

$152 R v$ Fairest [2016] VSC 329, [23]-[31].

153 Victorian Law Reform Commission, above n 43, 130 [5.26].
} 
The review of legislation and case law we have undertaken in this article suggests this 'ad hocery' applies across Australia, which clearly does not provide strong grounds for accused persons with disabilities to exercise their rights.

In the CRPD Committee's judgment on the case of Marlon Noble, it found that he had been discriminated against on the basis of disability, in violation of Art 5(1) and (2) of the CRPD, because he had not been provided with the 'support or accommodation he required to exercise his legal capacity', and the government 'did not analyse which measures could be adopted to do so'. ${ }^{154}$ Further, the Committee found that 'no adequate form of support was provided by the State party's authorities to enable him to stand trial and plead not guilty, despite his clear intention to do so'. ${ }^{155}$ The Committee determined that:

[W] hile States parties have a certain margin of appreciation to determine the procedural arrangements to enable persons with disabilities to exercise their legal capacity, the relevant rights of the person concerned must be respected. That did not happen in [Mr Noble's] case, as he had no possibility and was not provided with adequate support or accommodation to exercise his rights to access to justice and a fair trial. ${ }^{156}$

As such, the CRPD Committee found that Mr Noble's treatment amounted to a violation of his rights under Arts 12(2) and (3) and 13(1) of the CRPD. ${ }^{157}$ To remedy this, governments would need to ensure that people with disabilities are entitled without any discrimination to the equal protection and equal benefit of the law, including taking all appropriate steps to ensure that reasonable accommodation is provided to promote equality and eliminate discrimination. ${ }^{158}$ In its 2013 review of Australia's CRPD-compliance, the CRPD Committee recommended specifically that Australia 'establish binding guidelines to ensure appropriate support and accommodations for persons with disabilities in the criminal justice system'. ${ }^{159}$ More research is required to determine the best way to establish such guarantees. Regardless, it is clear that compliance with Arts 5(1) and (2), 12(2) and (3), and 13(1) of the CRPD requires procedural and age-appropriate supports to be widely available and consistently applied.

\section{Conclusion}

This article has focused on supports to optimise the fitness to stand trial of accused persons with cognitive disabilities. Courts have expressed a willingness to use support measures, including those that have enabled accused persons, whose fitness to stand trial was questioned, to proceed

154 Committee on the Rights of Persons with Disabilities, above n 12, 15 [8.4].

155 Ibid 15-16 [8.6].

156 Ibid.

157 Ibid 16 [8.6].

158 Ibid 15 [8.3].

159 Committee on the Rights of Persons with Disabilities, above n 9, [32]. 
to full trial. However, there remains clear scope to reinterpret, refine and strengthen these mechanisms with reference to Australia's obligations under international human rights law, and through participatory and interdisciplinary methods for discovering effective forms of support. Australia's obligations under the CRPD require minimum guarantees to procedural and age-appropriate accommodations to access justice, and to ensure sufficient support to exercise legal capacity in the criminal justice system. The importance of educating judicial staff is also a crucial way to ensure any legislative changes are employed consistently in courts.

The ambitious task of creating a universally accessible justice system, rather than having separate legal processes for persons with disabilities, is more likely to be achieved where empirical research establishes the type of supports that are effective in optimising participation in criminal proceedings, to which future research could turn. Refining such supports can then help with the design of legislation that ensures respect for legal capacity and access to justice for citizens with disabilities 'on an equal basis with others'. Improving the accessibility of criminal proceedings is likely to benefit not only persons with disabilities but others who may face barriers to participating in proceedings, including those in physical pain, older persons, people with low literacy or poor access to education, and so on. Ensuring accessibility in all sites in the administration of justice will prevent persons with cognitive disabilities and others facing the 'cruel lottery' of the supports that happen to be available in specific courts, police stations, or community legal centres in which they find themselves. 